\title{
Data report: permeability, consolidation properties, and grain size of sediments from Sites U1420 and U1421, offshore southern Alaska'
}

\author{
Hugh Daigle ${ }^{2}$ and Olivia L. Piña ${ }^{3}$
}

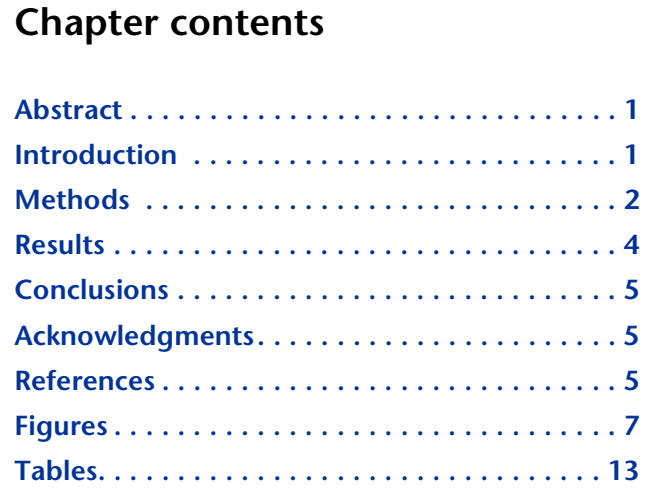

'Daigle, H., and Piña, O.L., 2016. Data report: permeability, consolidation properties, and grain size of sediments from Sites U1420 and U1421, offshore southern Alaska. In Jaeger, J.M., Gulick, S.P.S., LeVay, L.J., and the Expedition 341 Scientists, Proceedings of the Integrated Ocean Drilling Program, 341: College Station, TX (Integrated Ocean Drilling Program). doi:10.2204/iodp.proc.341.201.2016 ${ }^{2}$ Department of Petroleum and Geosystems Engineering, University of Texas at Austin, 200 East Dean Keeton Street, Stop C0300, Austin Texas 78712-1585, USA.

daigle@austin.utexas.edu

${ }^{3}$ Department of Civil, Environmental and Geodetic Engineering, The Ohio State University, 2070 Neil Avenue, Columbus Ohio 43210, USA.

\begin{abstract}
We performed uniaxial, constant-rate-of-strain consolidation experiments and grain size analyses to characterize the transport and deformation properties of eight samples from Integrated Ocean Drilling Program Expedition 341 Sites U1420 and U1421. Permeability, compression indexes, and swelling indexes were determined from consolidation experiments. Permeability values range from $1.2 \times 10^{-17} \mathrm{~m}^{2}$ to $2.0 \times 10^{-13} \mathrm{~m}^{2}$, are positively correlated with median grain diameter, and exhibit little depth dependence. Compression indexes, which define stress-strain behavior during virgin consolidation, range from 0.13 to 0.25 and are negatively correlated with median grain diameter. Swelling indexes, which define stress-strain behavior during elastic reconsolidation, range from 0.023 to 0.036 and are best correlated with compression indexes, generally being equal to $16.8 \%$ of the compression index value. Median grain diameters determined by Stokes settling analysis range from 0.00232 to $0.0969 \mathrm{~mm}$, with samples consisting of roughly equal portions of sand, silt, and clay. The standard deviations of the grain size distributions indicate that the sediment grains are very poorly sorted.
\end{abstract}

\section{Introduction}

Integrated Ocean Drilling Program (IODP) Expedition 341 was conducted to investigate the relationship among northwestern Cordilleran ice sheet glaciation, tectonic processes, and changes in regional and global paleoclimate (see the "Methods" chapter [Jaeger et al., 2014a]). IODP Sites U1420 and U1421 were drilled to sample sediments of the Pamplona zone, which is a fold and thrust belt that has accommodated shortening as a result of the underthrusting of the Yakutat terrane under North America (Worthington et al., 2010) (Fig. F1). Understanding the transport and deformation properties of these sediments and the factors that control them is a key component of understanding if and how loading through rapid sedimentation or glacial advance can alter the locus of deformation in tectonic wedges (e.g., Berger et al., 2008). This in turn provides key information to the Expedition 341 scientific goals.

We performed laboratory measurements of consolidation and fluid transport properties, as well as grain size, to constrain key properties of Pamplona zone sediments and understand the role 
that grain size plays in controlling these properties. We used whole-round samples for constant-rate-ofstrain (CRS) consolidation experiments to determine permeability, compression index, and swelling index. We performed grain size measurements on trimmings from CRS specimens to compare with the measured geotechnical properties. Our results provide important information on properties of the sediments in the Pamplona zone, which may be used to understand the role between glaciation, sedimentation, and tectonic deformation.

\section{Methods}

Whole-round samples were sealed and stored at $4^{\circ} \mathrm{C}$ to preserve pore fluids prior to testing. Shipboard selection of whole-round samples was conducted by the R/V JOIDES Resolution staff based on visual inspection to identify areas free of cracks and voids with minimal coring disturbance. Grain size measurements were performed on samples taken immediately adjacent to those used for CRS consolidation tests.

\section{CRS consolidation tests}

We performed CRS consolidation tests at room temperature $\left(22^{\circ} \mathrm{C}\right)$ following American Society for Testing and Materials (ASTM) International standards (ASTM International, 2006). Consolidation was performed in the vertical direction (parallel to the long axis of the core). The sample was first extruded from the core liner and trimmed into a fixed ring using a wire saw, spatula, and recess tool. After trimming, the initial sample dimensions were $2.41 \mathrm{~cm}$ in height and $5.09 \mathrm{~cm}$ in diameter. The ring and sample were then loaded into the sample chamber (Fig. F2). Alundum porous stones and woven polymer filter paper were placed on the top and base of the sample to allow drainage of pore fluid during consolidation. The sample chamber was sealed, filled with tap water, and placed in the consolidation frame. We then pressurized the sample chamber to $386 \mathrm{kPa}$ and left it for at least $8 \mathrm{~h}$ to ensure complete saturation. During the saturation stage, the stress on the piston actuator of the load frame was controlled to ensure zero axial strain.

After the saturation stage, the drain valve at the base of the sample was locked and the consolidation stage started. During consolidation, the axial strain rate $(\dot{\varepsilon})$ was held constant, and the fixed ring ensured zero radial strain. We monitored the pore pressure ratio (defined as $\left[P_{\mathrm{p}}-P_{\mathrm{c}}\right] / P_{\mathrm{c}}$, where $P_{\mathrm{p}}$ is the pore pressure at the base of the sample and $P_{\mathrm{c}}$ is the pressure in the consolidation chamber) and adjusted $\dot{\varepsilon}$ be- tween $0.5 \%$ and $1 \% / \mathrm{h}$ to maintain a pore pressure ratio between 0.01 and 0.15 . During the test, the total axial stress $\left(\sigma_{\mathrm{a}}\right)$, instantaneous sample height $(H)$, and $P_{\mathrm{p}}$ were recorded. We performed unload-reload cycles upon reaching $15 \%$ axial strain to assess the elastic consolidation properties of each sample. The unload cycle proceeded until reaching $10 \%$ of the value of $\sigma_{a}$ at the start of the unload cycle, followed by $18 \mathrm{~h}$ of creep. After the creep step, the sample was reloaded and consolidation proceeded until a final axial strain of $25 \%$ or $\sigma_{a}=22 \mathrm{MPa}$, whichever was reached first.

We used the data from the CRS consolidation tests to determine compression index $\left(C_{c}\right)$, swelling index $\left(C_{s}\right)$, and permeability $(k)$ (all nomenclature is provided in Table T1). $C_{c}$ describes the pore volume change during virgin consolidation (Fig. F3) (i.e., elasto-plastic strain that occurs at effective stresses greater than the maximum effective stress to which the sample has been subjected) (Craig, 1992) and was computed from the virgin consolidation portion of the test as

$$
C_{\mathrm{c}}=\left(e_{\sigma \mathrm{a}^{\prime}}-e_{\sigma \mathrm{a}^{\prime}+\Delta \sigma \mathrm{a}^{\prime}}\right) /\left[\log \left(\sigma_{\mathrm{a}}{ }^{\prime}-\Delta \sigma_{\mathrm{a}}{ }^{\prime} / \sigma_{\mathrm{a}}{ }^{\prime}\right)\right]
$$

where

$$
\begin{aligned}
C_{\mathrm{c}} & =\text { compression index } \\
e & =\text { void ratio, and } \\
\sigma_{\mathrm{a}}{ }^{\prime} & =\text { axial effective stress }(\mathrm{Pa}) .
\end{aligned}
$$

$C_{\mathrm{s}}$ describes the pore volume change during elastic reconsolidation (Fig. F3) (i.e., recoverable stain that occurs at effective stresses less than the maximum effective stress to which the sample has been subjected) (Craig, 1992) and was computed from the reload portion of the test using Equation 1. Void ratio was determined from the initial void ratio of the sample and strain data recorded during the test; initial void ratio was determined from mass and density measurements following the method of Blum (1997). It is important to note that the value of $\sigma_{a}{ }^{\prime}$ that separates elastic reconsolidation from virgin consolidation is affected by in situ stresses the sediment has experienced as well as stresses imparted during core recovery. The in situ stresses experienced by sediments at Sites U1420 and U1421 are further complicated by a history of glaciation extending over these locations at various times in the past (Manley and Kaufman, 2002). The results of the consolidation experiments must therefore be interpreted with care.

Permeability during the test was computed as

$$
k=\left(\dot{\varepsilon} H H_{0} \mu\right) /(2 \Delta u),
$$


where

$$
\begin{aligned}
k & =\text { permeability }\left(\mathrm{m}^{2}\right), \\
\dot{\varepsilon} & =\text { strain rate }(1 / \mathrm{s}), \\
H & =\text { instantaneous specimen height }(\mathrm{m}), \\
H_{0} & =\text { initial specimen height }(\mathrm{m}), \\
\mu & =\text { dynamic viscosity of pore fluid }(\mathrm{Pa} \cdot \mathrm{s}), \text { and } \\
\Delta u & =\text { base excess pressure }(\mathrm{Pa}) .
\end{aligned}
$$

We assumed $\mu=0.001 \mathrm{~Pa} \cdot \mathrm{s}$. We computed $\Delta u$ as the difference between the pore pressure at the base of the sample and the fluid pressure in the consolidation cell $\left(\Delta u=P_{\mathrm{p}}-P_{\mathrm{c}}\right)$. In the permeability computation, $\Delta u$ was smoothed using a six-point moving average, and the resulting permeabilities were extrapolated to the initial permeability $\left(k_{0}\right)$ at the initial porosity of the sample by assuming a log-linear relationship between permeability and porosity during virgin consolidation (e.g., Neuzil, 1994) (Fig. F4).

We used permeability and effective stress data to determine the coefficient of consolidation $\left(c_{\mathrm{v}}\right)$ during the test (ASTM International, 2006; Craig, 1992):

$$
c_{\mathrm{v}}=k / \mu m_{\mathrm{v}}
$$

where

$$
\begin{aligned}
& c_{\mathrm{v}}=\text { coefficient of consolidation }\left(\mathrm{m}^{2} / \mathrm{s}\right), \\
& k=\text { permeability }\left(\mathrm{m}^{2}\right), \\
& \mu=\text { dynamic viscosity of pore fluid }(\mathrm{Pa} \cdot \mathrm{s}), \text { and } \\
& m_{\mathrm{v}}=\text { coefficient of volume compressibility }(1 / \mathrm{Pa}) .
\end{aligned}
$$

The coefficient of volume compressibility is defined as the change in axial strain per unit increase in axial effective stress (Craig, 1992) and was computed as

$$
m_{\mathrm{v}}=\left(\varepsilon_{\sigma \mathrm{a}^{\prime}+\Delta \sigma \mathrm{a}^{\prime}}-\varepsilon_{\sigma \mathrm{a}^{\prime}}\right) /\left[\left(\sigma_{\mathrm{a}}{ }^{\prime}+\Delta \sigma_{\mathrm{a}}{ }^{\prime}\right)-\sigma_{\mathrm{a}}{ }^{\prime}\right],
$$

where $\varepsilon=$ axial strain.

\section{Grain size measurements}

We conducted grain size measurements following the ASTM standard for particle-size analysis (ASTM International, 2007). Trimmings from the CRS consolidation sample were oven-dried at $105^{\circ} \mathrm{C}$ for at least $24 \mathrm{~h}$ and powdered using a ceramic mortar and pestle. Following this, the powdered samples were passed through a $2 \mathrm{~mm}$ sieve. A total of $50 \mathrm{~g}$ of the portion of the sample that passed through the $2 \mathrm{~mm}$ sieve was then mixed with deionized water and $5 \mathrm{~g}$ of sodium hexametaphosphate deflocculant and left to soak for at least $16 \mathrm{~h}$. After soaking, the samples were further dispersed using a milkshake mixer, poured into a glass settling column, and diluted with deionized water to a total volume of $1 \mathrm{~L}$. After dilution, the column was agitated for $60 \mathrm{~s}$ and then left to settle. During settling, the bulk density of the solution was measured periodically using ASTM Hydrometer $151 \mathrm{H}$. The mass fraction of particles remaining in suspension $\left(m_{\mathrm{p}}\right)$ at the time of hydrometer measurement is given by

$$
m_{\mathrm{p}}=\left[\rho_{\mathrm{s}} V\left(\rho-\rho_{\mathrm{f}}\right)\right] /\left[\left(\rho_{\mathrm{s}}-1000\right) m_{\mathrm{s}}\right]
$$

where

$$
\begin{aligned}
m_{\mathrm{p}}= & \text { mass fraction of particles remaining in sus- } \\
& \text { pension, } \\
\rho_{\mathrm{s}}= & \text { specimen grain density, } \\
V= & \text { volume of solution }\left(\mathrm{m}^{3}\right), \\
m_{\mathrm{s}}= & \text { dry mass of specimen }(\mathrm{kg}), \\
\rho= & \text { hydrometer reading }\left(\mathrm{kg} / \mathrm{m}^{3}\right), \text { and } \\
\rho_{\mathrm{f}}= & \text { density of solution fluid without sediment } \\
& \left(\mathrm{kg} / \mathrm{m}^{3}\right) .
\end{aligned}
$$

The specimen grain density was determined by taking the average of the grain density values determined by shipboard moisture and density (MAD) measurements at each site $\left(2800 \mathrm{~kg} / \mathrm{m}^{3}\right.$ at Site U1420 and $2890 \mathrm{~kg} / \mathrm{m}^{3}$ at Site U1421). The maximum grain diameter $(D)$ of the particles still in suspension at the time of each hydrometer measurement is given by

$$
D=\sqrt{\frac{30 \times \mu \times L}{t\left(\rho_{\mathrm{s}}-1000\right)}} \mathrm{g}^{\prime}
$$

where

$$
\begin{aligned}
D= & \text { equivalent particle diameter }(\mathrm{m}), \\
\mu= & \text { solution fluid viscosity }(\mathrm{Pa} \cdot \mathrm{s}), \\
L= & \text { effective depth from solution surface to center } \\
& \text { of hydrometer bulb }(\mathrm{m}), \\
t= & \text { time of hydrometer measurement }(\mathrm{s}), \text { and } \\
\mathrm{g}= & \text { acceleration due to gravity }\left(\mathrm{m} / \mathrm{s}^{2}\right) .
\end{aligned}
$$

$L$ was determined for Hydrometer $151 \mathrm{H}$ from table 2 of the ASTM standard (ASTM International, 2007).

Because all the hydrometer analyses indicated that a significant fraction of the particles settled out prior to the first hydrometer reading ( $15 \mathrm{~s}$ after the end of the agitation, corresponding to $D=0.081 \mathrm{~mm}$ from Equation 6), we performed sieve analysis on separate aliquots of the bulk powdered samples using a set of sieves with mesh openings of 12.7, 9.52, 6.35, 4.75, $2.38,2.00,1.70,1.40,1.18,1.00,0.850,0.600$, and $0.425 \mathrm{~mm}$. The results of the sieve analyses were merged with the hydrometer results to yield the complete grain size distribution. The median grain diameter was determined from this complete grain size distribution. Relative mass fractions of sand, silt, and clay were determined using grain diameter cutoffs of $0.0625 \mathrm{~mm}$ for sand-silt and $0.002 \mathrm{~mm}$ for silt-clay. We quantified the degree of sorting by determining the standard deviation $(\sigma)$ of the distributions in $\varphi$ units following the method of Folk and Ward (1957). 


\section{Results}

Consolidation and grain size data are summarized in Table T2. Complete experiment data for consolidation (341_CONSOL) and grain size (341_GRAIN_SIZE) are provided in "Supplementary material."

Our laboratory-determined porosity values are within the range of the values determined by shipboard MAD measurements (Fig. F5). It should be noted that both the MAD values and our values include movable water and water bound to clay mineral surfaces and in clay interlayers; therefore, the porosities obtained represent the total porosity (Daigle, 2014).

Laboratory measurements are plotted against depth in Figures F6 and F7. The depth reference is meters core depth below seafloor (CSF-A), which uses the core section length for depth determination and does not include a core expansion correction (see IODP Depth Scales Terminology, v.2, at http:// www.iodp.org/program-documents/). Permeabilities $\left(k_{0}\right)$ determined from CRS consolidation experiments range from $1.2 \times 10^{-17} \mathrm{~m}^{2}$ to $2.0 \times 10^{-13} \mathrm{~m}^{2}$ and exhibit little trend with depth. Compression indexes $\left(C_{c}\right)$ range from 0.13 to 0.25 , and swelling indexes $\left(C_{\mathrm{s}}\right)$ range from 0.023 to 0.036 . The $C_{\mathrm{s}} / C_{\mathrm{c}}$ ratio can be used to quantify the fraction of virgin consolidation that is recoverable during unloading. For our data set, $C_{\mathrm{s}}$ can be fit as $16.8 \%$ of $C_{\mathrm{c}}$ with a coefficient of determination $\left(R^{2}\right)$ of 0.40 (Fig. F8). Neither $C_{\mathrm{c}}$ nor $C_{\mathrm{s}}$ exhibit any depth dependence. Median grain diameters $\left(D_{50}\right)$ range from 0.00232 to $0.0969 \mathrm{~mm}$. The grains are generally very poorly sorted in the classification scheme of Folk and Ward (1957), consisting of roughly equal portions of sand-, silt-, and clay-sized grains (Fig. F9) and exhibiting $\sigma$ values ranging from $2.3 \varphi$ to $4.1 \varphi$.

Global studies of permeability of marine sediments (Gamage et al., 2011; Daigle and Screaton, 2015) have shown that grain size exerts a first-order control on permeability. Specifically, the relative mass fractions of clay-sized versus larger particles are important determiners of permeability and porosity changes during burial, because a greater abundance of larger particles will shield the clay from consolidation during burial (Schneider et al., 2011; Reece et al., 2013). We did not observe any correlation between $k_{0}$ and the clay-sized fraction for the samples we measured (Fig. F10A). However, we did observe a weak correlation between $C_{\mathrm{c}}$ and the clay-sized fraction, with higher clay content corresponding to larger $C_{c}$ (Fig. F10B). This is consistent with the experimental data of Reece et al. (2013) for samples from the Nankai Trough. Although $k_{0}$ and $C_{\mathrm{c}}$ should exhibit dependence on porosity (Scheidegger, 1963; Long et al., 2011), we did not observe any such trends. This is probably due to the small range of porosities among these samples (0.33-0.41).

Because all of our measurements were performed in the laboratory, the results may have been affected by sample disturbance introduced during the coring and preparation processes. We selected the specific intervals for testing from each $\sim 30 \mathrm{~cm}$ long wholeround based on visual inspection, and all of the tested intervals appeared free of cracks and voids. However, none of the CRS consolidation experiments showed evidence of a preconsolidation stress, which would have been apparent as an inflection point in the $e-\log \left(\sigma_{v}{ }^{\prime}\right)$ curve (Casagrande, 1936). Because all samples were from at least $492.63 \mathrm{~m}$ CSF-A, a nonzero preconsolidation stress should be expected. The lack of apparent preconsolidation stress is likely due to sample disturbance during coring. Because of the abundance of large clasts in the sediment at Sites U1420 and U1421, core recovery was problematic, with frequent jamming of the core catcher (see the "Site U1420" and "Site U1421" chapters [Jaeger et al., 2014b, 2014c]). Coring-induced disturbance typically alters the fabric of the clay fraction of the sediment, resulting in apparent lower preconsolidation stresses or complete remolding and stress history erasure in severe cases (Silva and Hollister, 1973; La Rochelle et al., 1981; Saffer et al., 2011; Daigle and Dugan, 2014). We conclude that our samples were strongly influenced by coring disturbance. This highlights the importance of the use of consolidation experiments to estimate in situ permeability in remolded samples.

It is important to note that the value of $\sigma_{a}{ }^{\prime}$ that separates elastic reconsolidation from virgin consolidation is affected by in situ stresses the sediment has experienced and stresses imparted during core recovery. The in situ stresses experienced by sediments at Sites U1420 and U1421 are further complicated by a history of glaciation extending over these locations at various times in the past (Manley and Kaufman, 2002). If the in situ fabric of the sediments had been preserved, we would expect that the glaciation history at these locations would cause the sediments to have large maximum preconsolidation stresses and that all of the stress-strain data recorded in the laboratory would correspond to elastic reconsolidation. However, because we observed distinctly different values of $C_{\mathrm{c}}$ and $C_{\mathrm{s}}$ in all samples, and as mentioned previously, there were no inflection points observed in the stress-strain curves. 


\section{Conclusions}

We performed CRS consolidation experiments and hydrometer measurements to characterize the consolidation, transport, and grain size characteristics of sediments recovered from Expedition 341 Sites U1420 and U1421. We found that compression indexes, swelling indexes, and permeability exhibited very little trend with depth at either site, but both compression index and permeability followed power-law relationships with median grain diameter. Greater clay-sized fractions were correlated with higher compression indexes, but no correlation was observed between the clay-sized fraction and permeability. Swelling index was consistently $\sim 16.8 \%$ of the compression index. Samples generally had equal portions of sand-, silt-, and clay-sized particles, and the large standard deviations of the grain size distributions indicated very poor sorting. The data recorded during CRS consolidation experiments suggested that the samples had undergone severe coring disturbance, with no evidence of preconsolidation stress. Our measurements provide important information on the physical properties of sediments within the Pamplona zone.

\section{Acknowledgments}

Samples and data were provided by the Integrated Ocean Drilling Program (IODP). Funding was provided by the University of Texas at Austin Department of Petroleum and Geosystems Engineering Summer Undergraduate Research Internship (SURI) program. The authors thank the science party and technical staff of IODP Expedition 341, whose efforts made this work possible.

\section{References}

ASTM International, 2006. Standard test methods for specific gravity of soil solids by water pycnometer (D85406e1). In Annual Book of ASTM Standards (Vol 04.08): Soil and Rock (I): West Conshohocken, PA (Am. Soc. Testing Mater.). http://www.astm.org/DATABASE.CART/ HISTORICAL/D854-06E1.htm

ASTM International, 2007. Standard test method for particle-size analysis of soils (Standard D422-63[2007]). In Annual Book of ASTM Standards (Vol. 04.08): Soil and Rock (I): West Conshohocken, PA (Am. So. Testing Mater.). http://dx.doi.org/10.1520/D0422-63R07

Berger, A.L., Gulick, S.P.S., Spotila, J.A., Upton, P., Jaeger, J.M., Chapman, J.B., Worthington, L.A., Pavlis, T.L., Ridgway, K.D., Willems, B.A., and McAleer, R.J., 2008. Quaternary tectonic response to intensified glacial erosion in an orogenic wedge. Nature Geoscience, 1:793799. http://dx.doi.org/10.1038/ngeo334
Blum, P., 1997. Physical properties handbook: a guide to the shipboard measurement of physical properties of deep-sea cores. Ocean Drilling Program Technical Note, 26. http://dx.doi.org/10.2973/odp.tn.26.1997

Casagrande, A., 1936. The determination of pre-consolidation load and its practical significance. In Casagrande, A., Rutledge, P.C., and Watson, J.D. (Eds.), Proc. 1st Int. Conf. Soil Mech. Found. Eng. Am. Soc. Civ. Eng., 3:60-64.

Craig, R.F., 1992. Soil Mechanics (5th ed.): London (Chapman and Hall).

Daigle, H., 2014. Microporosity development in shallow marine sediments from the Nankai Trough. Marine Geology, 357:293-303.

http://dx.doi.org/10.1016/j.margeo.2014.09.041

Daigle, H., and Dugan, B., 2014. Data report: permeability, consolidation, stress state, and pore system characteristics of sediments from Sites C0011, C0012, and C0018 of the Nankai Trough. In Henry, P., Kanamatsu, T., Moe, K., and the Expedition 333 Scientists, Proceedings of the Integrated Ocean Drilling Program, 333: Tokyo (Integrated Ocean Drilling Program Management International, Inc.).

http://dx.doi.org/10.2204/iodp.proc.333.201.2014

Daigle, H., and Screaton, E.J., 2015. Evolution of sediment permeability during burial and subduction. Geofluids, 15(1-2):84-105. http://dx.doi.org/10.1111/gfl.12090

Folk, R.L., and Ward, W.C., 1957. Brazos River bar [Texas]: a study in the significance of grain size parameters. Journal of Sedimentary Research, 27(1):3-26. http:// dx.doi.org/10.1306/74D70646-2B21-11D78648000102C1865D

Gamage, K., Screaton, E., Bekins, B., and Aiello, I., 2011. Permeability-porosity relationships of subduction zone sediments. Marine Geology, 279(1-4):19-36. http://dx.doi.org/10.1016/j.margeo.2010.10.010

Jaeger, J.M., Gulick, S.P.S., LeVay, L.J., Asahi, H., Bahlburg, H., Belanger, C.L., Berbel, G.B.B., Childress, L.B., Cowan, E.A., Drab, L., Forwick, M., Fukumura, A., Ge, S., Gupta, S.M., Kioka, A., Konno, S., März, C.E., Matsuzaki, K.M., McClymont, E.L., Mix, A.C., Moy, C.M., Müller, J., Nakamura, A., Ojima, T., Ridgway, K.D., Rodrigues Ribeiro, F., Romero, O.E., Slagle, A.L., Stoner, J.S., St-Onge, G., Suto, I., Walczak, M.H., and Worthington, L.L., 2014a. Methods. In Jaeger, J.M., Gulick, S.P.S., LeVay, L.J., and the Expedition 341 Scientists, Proceedings of the Integrated Ocean Drilling Program, 341: College Station, TX (Integrated Ocean Drilling Program). http://dx.doi.org/10.2204/iodp.proc.341.102.2014

Jaeger, J.M., Gulick, S.P.S., LeVay, L.J., Asahi, H., Bahlburg, H., Belanger, C.L., Berbel, G.B.B., Childress, L.B., Cowan, E.A., Drab, L., Forwick, M., Fukumura, A., Ge, S., Gupta, S.M., Kioka, A., Konno, S., März, C.E., Matsuzaki, K.M., McClymont, E.L., Mix, A.C., Moy, C.M., Müller, J., Nakamura, A., Ojima, T., Ridgway, K.D., Rodrigues Ribeiro, F., Romero, O.E., Slagle, A.L., Stoner, J.S., St-Onge, G., Suto, I., Walczak, M.H., and Worthington, L.L., 2014b. Site U1420. In Jaeger, J.M., Gulick, S.P.S., LeVay, L.J., and the Expedition 341 Scientists, Proceedings of the Integrated Ocean Drilling Program, 341: Col- 
lege Station, TX (Integrated Ocean Drilling Program). http://dx.doi.org/10.2204/iodp.proc.341.106.2014

Jaeger, J.M., Gulick, S.P.S., LeVay, L.J., Asahi, H., Bahlburg, H., Belanger, C.L., Berbel, G.B.B., Childress, L.B., Cowan, E.A., Drab, L., Forwick, M., Fukumura, A., Ge, S., Gupta, S.M., Kioka, A., Konno, S., März, C.E., Matsuzaki, K.M., McClymont, E.L., Mix, A.C., Moy, C.M., Müller, J., Nakamura, A., Ojima, T., Ridgway, K.D., Rodrigues Ribeiro, F., Romero, O.E., Slagle, A.L., Stoner, J.S., St-Onge, G., Suto, I., Walczak, M.H., and Worthington, L.L., 2014c. Site U1421. In Jaeger, J.M., Gulick, S.P.S., LeVay, L.J., and the Expedition 341 Scientists, Proceedings of the Integrated Ocean Drilling Program, 341: College Station, TX (Integrated Ocean Drilling Program). http://dx.doi.org/10.2204/iodp.proc.341.107.2014

La Rochelle, P., Sarrailh, J., Tavenas, F., Roy, M., and Leroueil, S., 1981. Causes of sampling disturbance and design of a new sampler for sensitive soils. Canadian Geotechnical Journal, 18(1):52-66. http://dx.doi.org/10.1139/t81-006

Long, H., Flemings, P.B., Germaine, J.T., and Saffer, D.M., 2011. Consolidation and overpressure near the seafloor in the Ursa Basin, deepwater Gulf of Mexico. Earth and Planetary Science Letters, 305(1-2):11-20. http://dx.doi.org/10.1016/j.epsl.2011.02.007

Manley, W., and Kaufman, D.S., 2002. Alaska Paleoglacier Atlas: Boulder, CO (Inst. Arct. Alp. Res., Univ. Colorado). http://instaar.colorado.edu/QGISL/ak_paleoglacier_atlas/

Neuzil, C.E., 1994. How permeable are clays and shales? Water Resources Research, 30(2):145-150. http://dx.doi.org/10.1029/93WR02930

Reece, J.S., Flemings, P.B., and Germaine, J.T., 2013. Data report: permeability, compressibility, and microstructure of resedimented mudstone from IODP Expedition 322, Site C0011. In Saito, S., Underwood, M.B., Kubo, Y., and the Expedition 322 Scientists, Proceedings of the Inte- grated Ocean Drilling Program, 322: Tokyo (Integrated Ocean Drilling Program Management International, Inc.).

http://dx.doi.org/10.2204/iodp.proc.322.205.2013

Saffer, D., Guo, J., Underwood, M.B., Likos, W., Skarbek, R.M., Song, I., and Gildow, M., 2011. Data report: consolidation, permeability, and fabric of sediments from the Nankai continental slope, IODP Sites C0001, C0008, and C0004. In Kinoshita, M., Tobin, H., Ashi, J., Kimura, G., Lallemant, S., Screaton, E.J., Curewitz, D., Masago, H., Moe, K.T., and the Expedition 314/315/316 Scientists, Proceedings of the Integrated Ocean Drilling Program, 314/315/316: Washington, DC (Integrated Ocean Drilling Program Management International, Inc.). http:// dx.doi.org/10.2204/iodp.proc.314315316.218.2011

Scheidegger, A.E., 1963. The Physics of Flow through Porous Media (2nd ed.): Toronto (University of Toronto Press).

Schneider, J., Flemings, P.B., Day-Stirrat, R.J., and Germaine, J.T., 2011. Insights into pore-scale controls on mudstone permeability through resedimentation experiments. Geology, 39(11):1011-1014. http://dx.doi.org/10.1130/G32475.1

Silva, A.J., and Hollister, C.D., 1973. Geotechnical properties of ocean sediments recovered with giant piston corer: 1. Gulf of Maine. Journal of Geophysical Research, 78(18):3597-3616.

http://dx.doi.org/10.1029/JC078i018p03597

Worthington, L.L, Gulick, S.P.S., and Pavlis, T.L., 2010. Coupled stratigraphic and structural evolution of a glaciated orogenic wedge, offshore St. Elias orogen, Alaska. Tectonics, 29:TC6013-TC6039. http://dx.doi.org/10.1029/2010TC002723

Initial receipt: 5 January 2014

Acceptance: 7 December 2015

Publication: 26 February 2016

MS 341-201 
Figure F1. A. Location map showing Sites U1420 and U1421 offshore southern Alaska along with regional tectonic features. B. Seismic Line GOA2505 showing of Sites U1420 and U1421 location along with horizon interpretation. Horizon topography is related to folding and thrusting in the Pamplona zone. Images modified from Worthington et al. (2010). YAK-NA = Yakutat-North America. VE = vertical exaggeration.
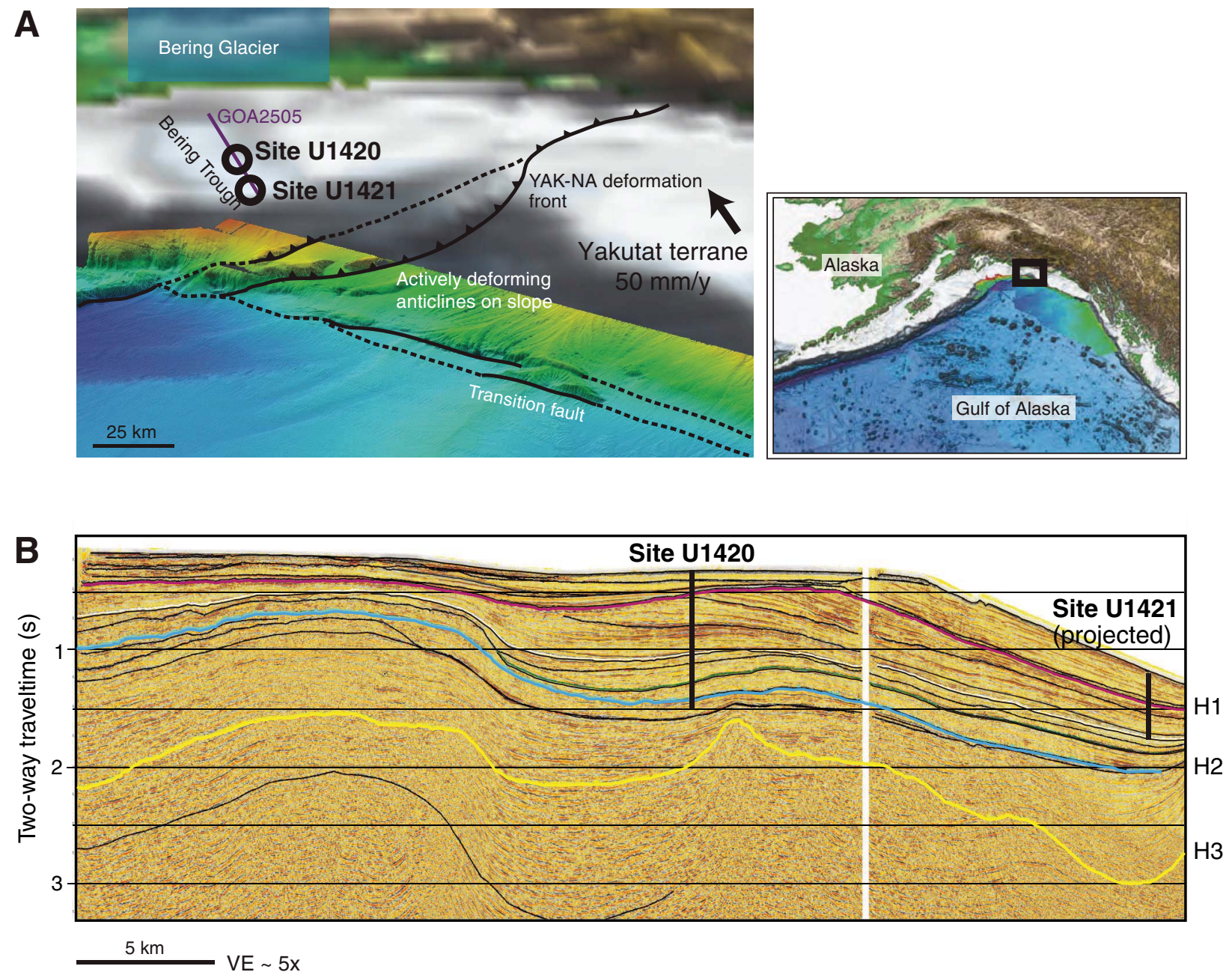
Figure F2. Diagram of consolidation cell used for CRS consolidation experiments. Pumps, flow lines, and transducers not shown to scale.

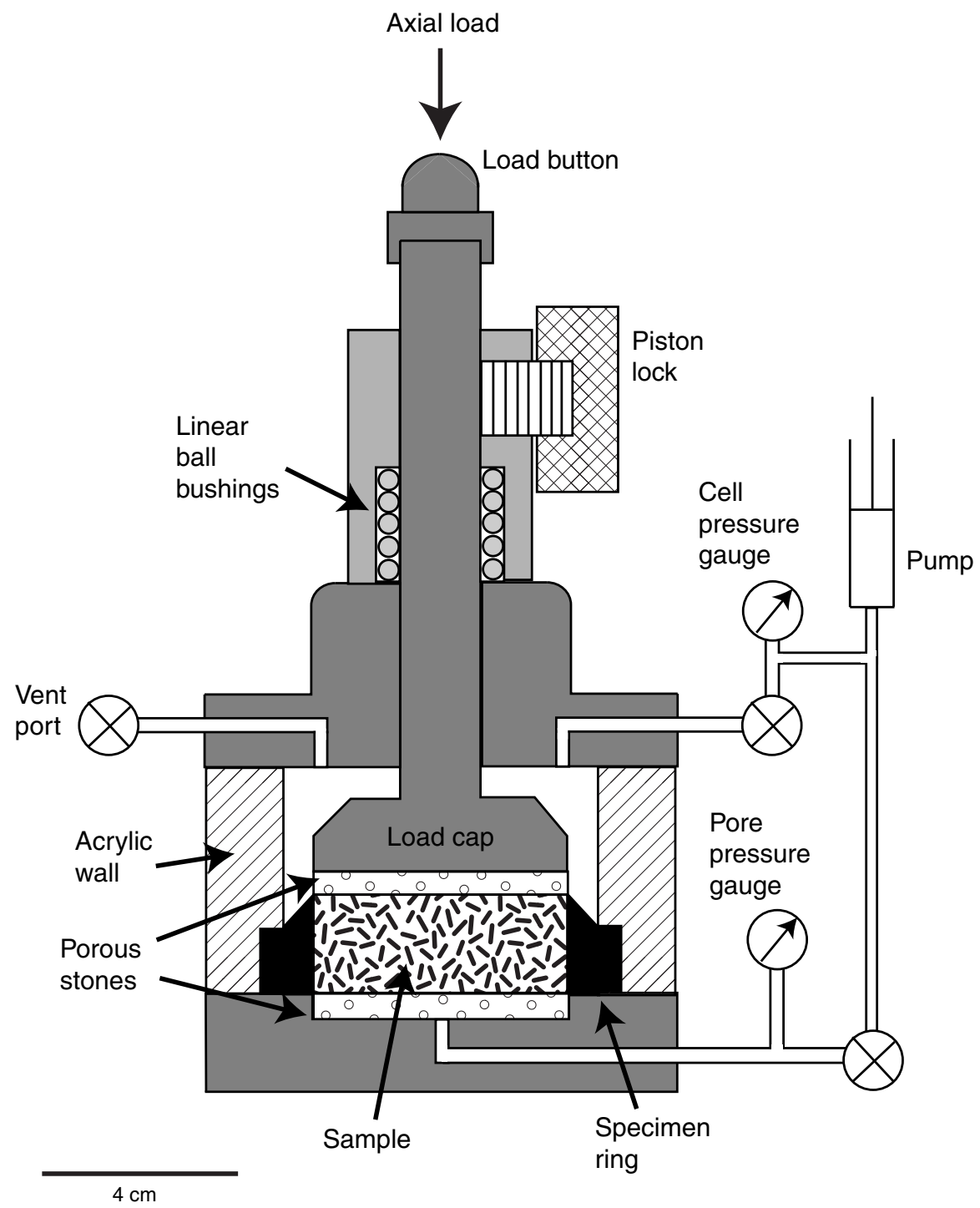


Figure F3. Example $e$ - $\log \sigma_{v^{\prime}}$ showing determination of $C_{c}$ and $C_{s}$. Data from Sample 341-U1420A-92R-1, 129$133 \mathrm{~cm}$ (Test CRS007). $C_{c}$ was determined as slope of line fit to linear portion of data during virgin consolidation following unload-reload cycle (solid line), $C_{s}$ was determined as slope of line fit to linear portion of data during reload stage (dashed line).

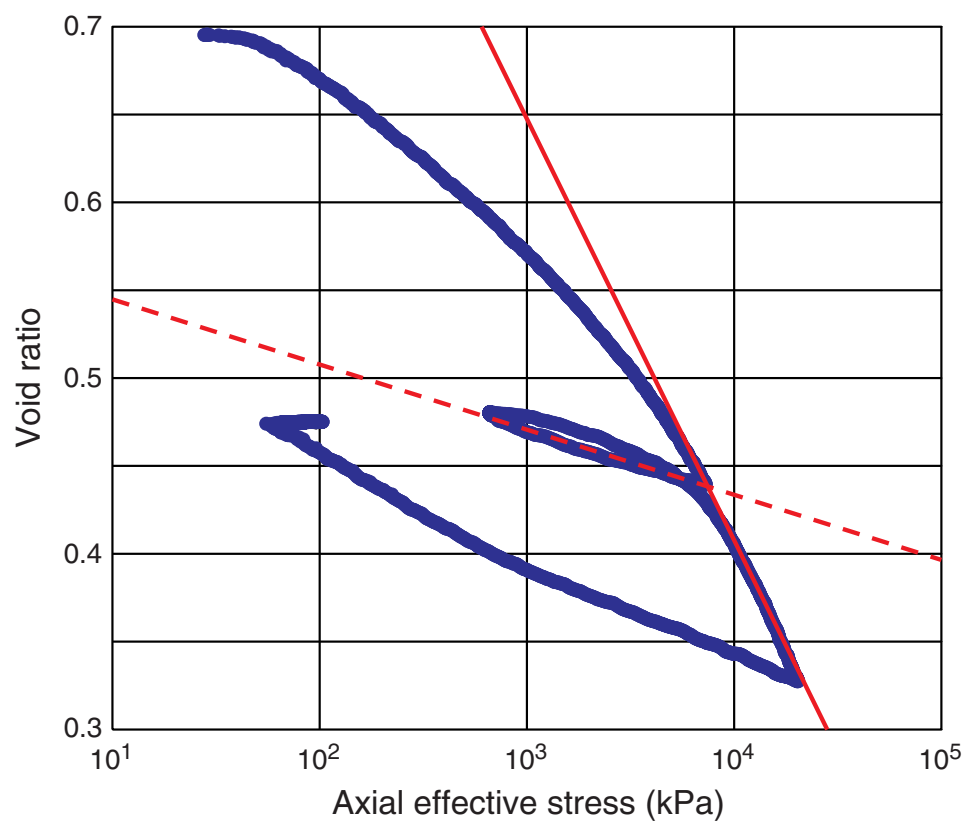

Figure F4. Example of $k_{0}$ determination. A line is fit to porosity-log $(k)$ data from the virgin consolidation portion of the CRS consolidation experiment (red line). Line is then extrapolated to in situ porosity to determine $k_{0}$. Data shown are for Sample 341-U1420A-92R-1, 129-133 cm (Test CRS007), with initial porosity of 0.41 and $k_{0}=1.25 \times 10^{-17} \mathrm{~m}^{2}$ (white circle).

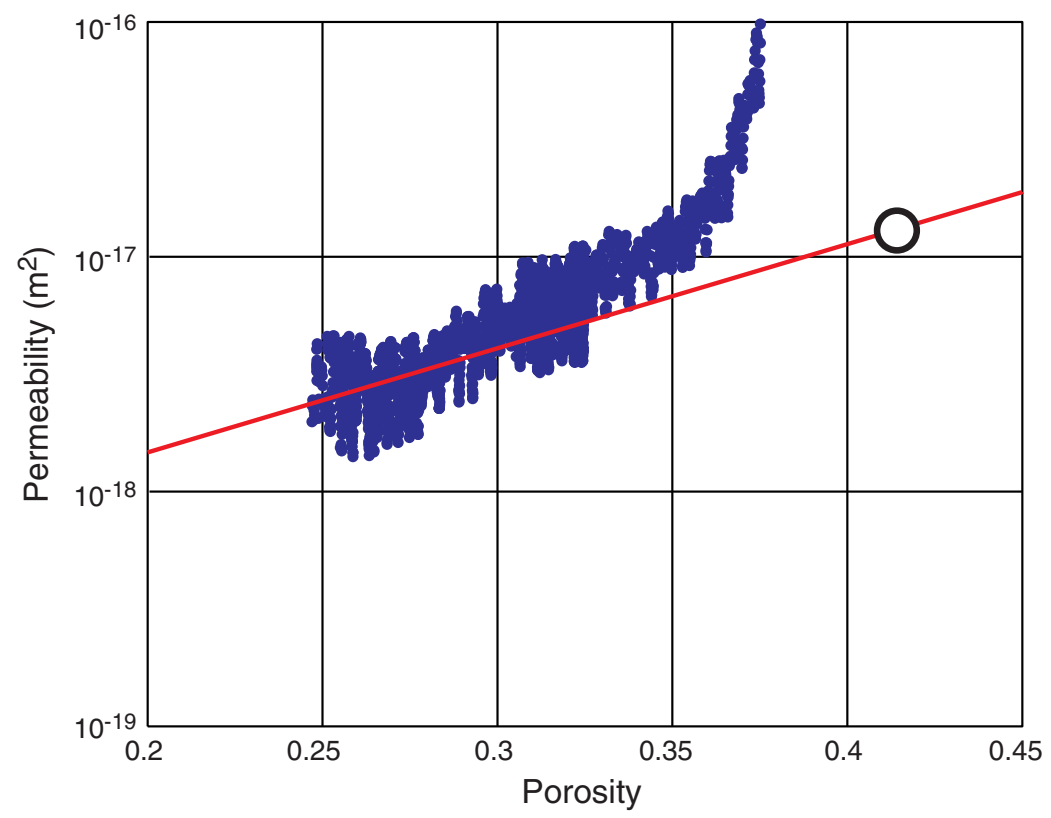


Figure F5. Comparison of shipboard MAD porosity values with those we obtained in the laboratory for Sites U1420 and U1421. Lithologic unit boundaries (see the "Site U1420" and "Site U1421" chapters [Jaeger et al., 2014b, 2014c]) are shown for reference.
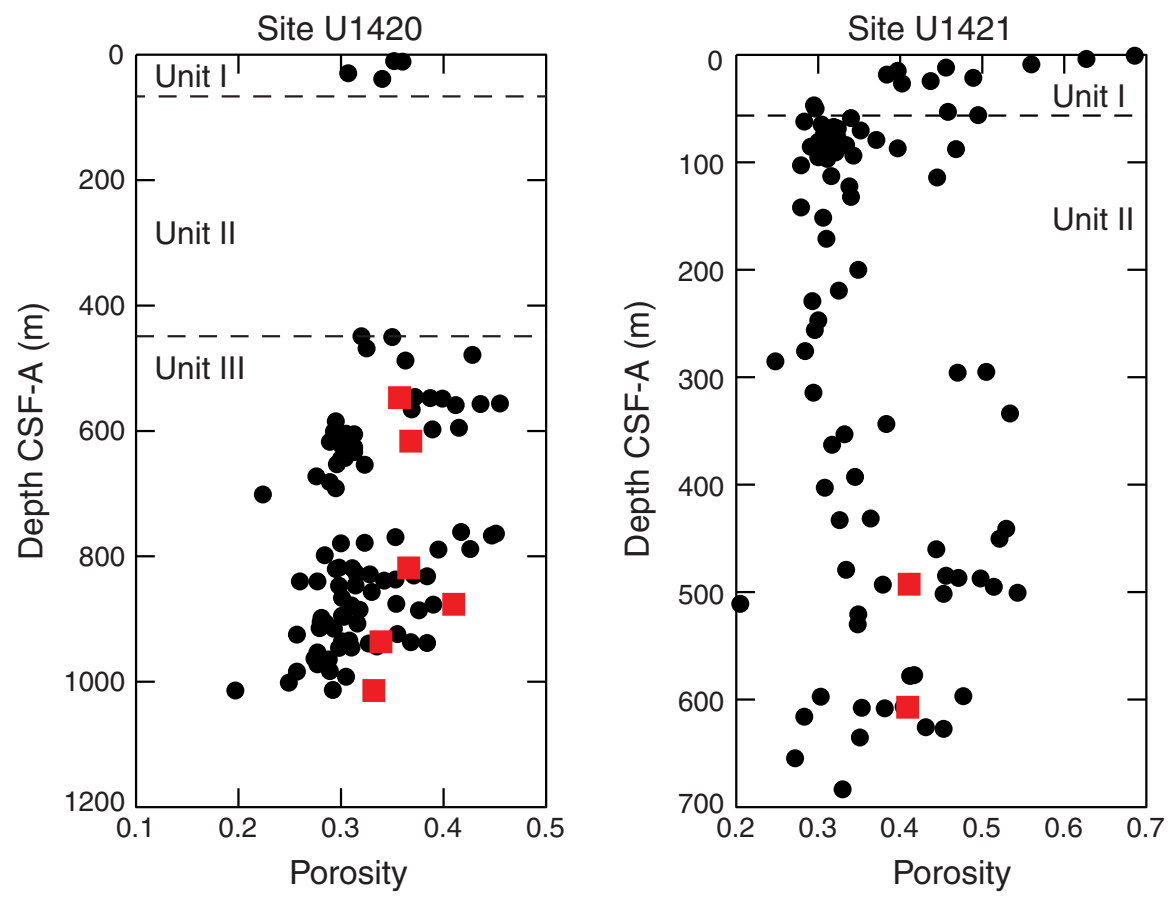

Shipboard MAD

Laboratory

Figure F6. Laboratory results, Site U1420. A. Permeability $\left(k_{0}\right)$. B. Compression index $\left(C_{c}\right)$. C. Swelling index $\left(C_{s}\right)$. D. Median grain diameter $\left(D_{50}\right)$. E. Sand-, silt-, and clay-sized fractions. F. Standard deviation of grain size distribution $(\sigma)$ in $\varphi$ units.
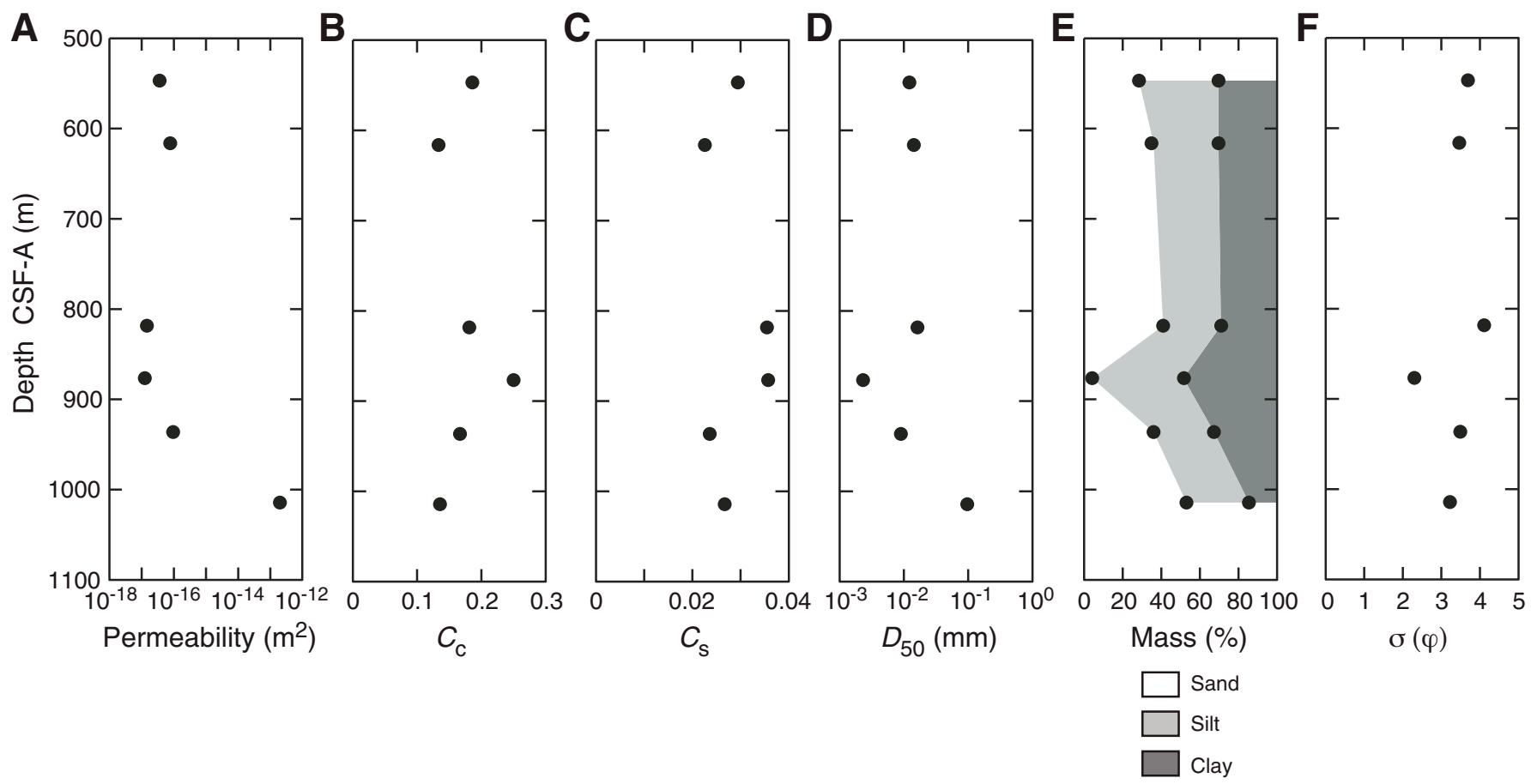
Figure F7. Laboratory results, Site U1421. A. Permeability $\left(k_{0}\right)$. B. Compression index $\left(C_{c}\right)$. C. Swelling index $\left(C_{s}\right)$. D. Median grain diameter $\left(D_{50}\right)$. E. Sand-, silt-, and clay-sized fractions. F. Standard deviation of grain size distribution $(\sigma)$ in $\varphi$ units.
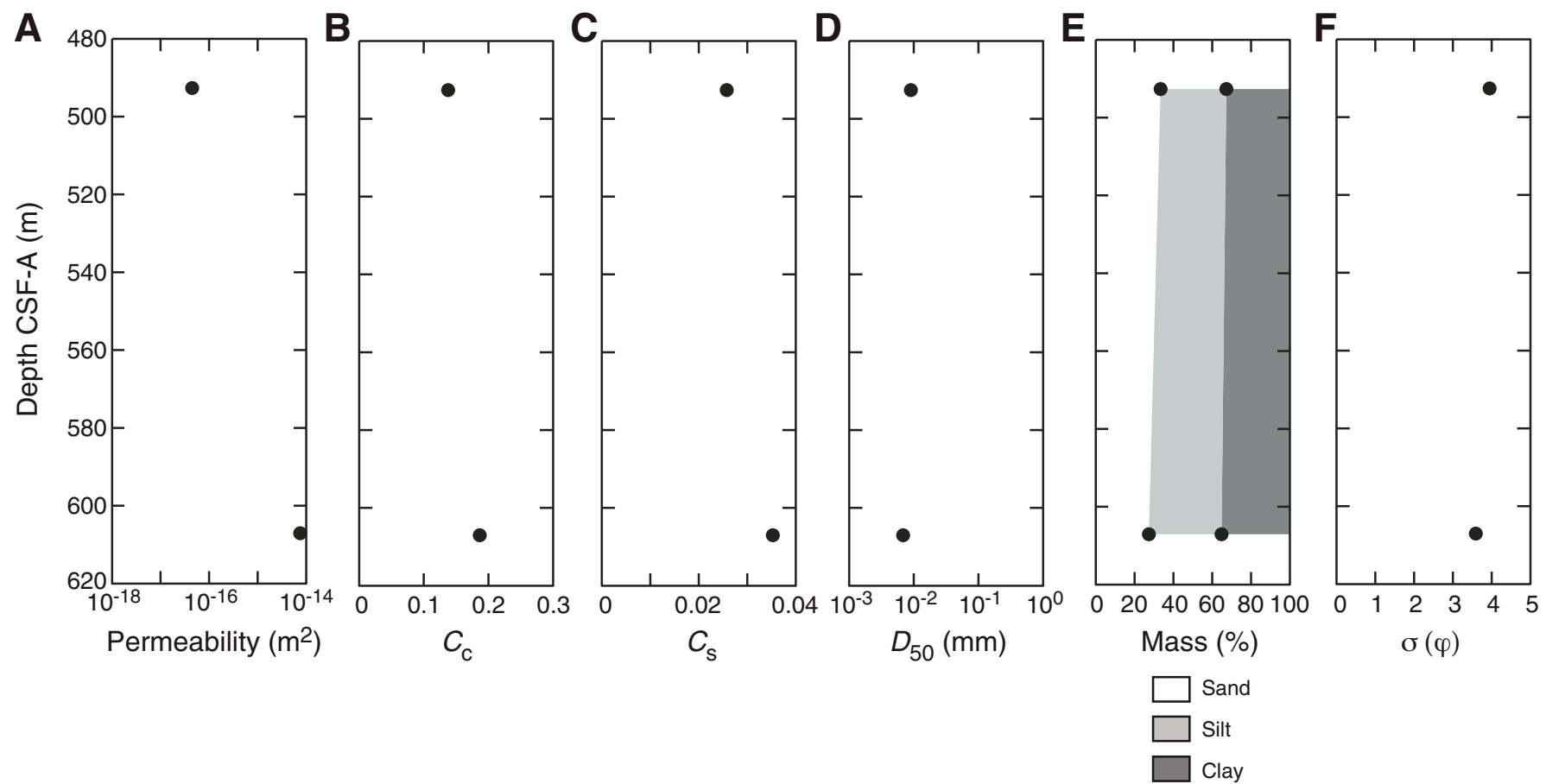

Figure F8. Relationship between $C_{\mathrm{c}}$ and $C_{s}$, Sites U1420 and U1421. $C_{s}$ may be determined as $0.168 C_{\mathrm{c}}$ (dashed line) with a coefficient of determination $\left(R^{2}\right)$ of 0.40 .

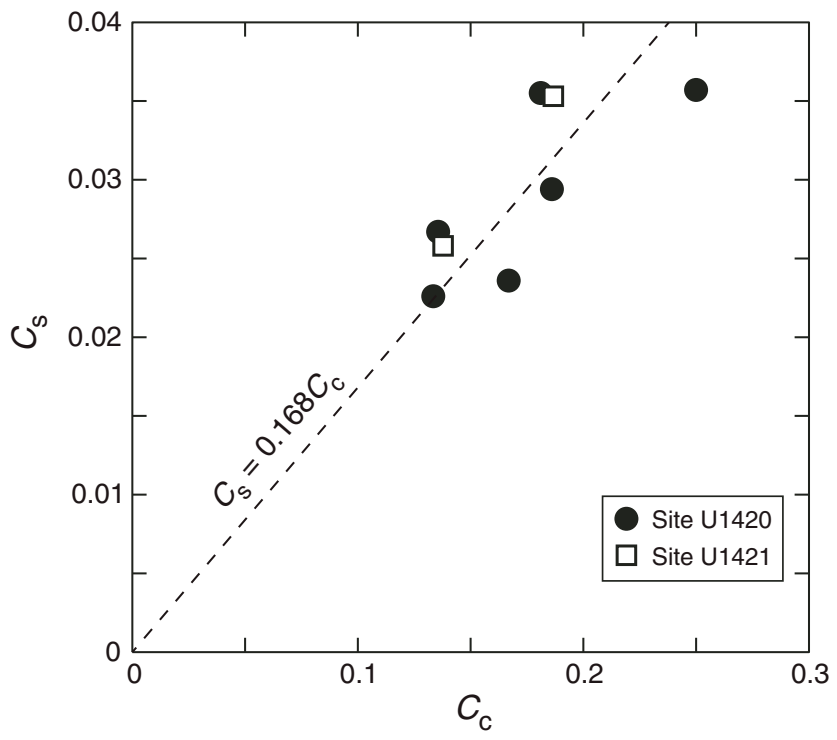


Figure F9. Cumulative grain size distributions for all samples. Dashed lines = grain-size cutoffs for sand $(0.0625$ $\mathrm{mm})$ and clay $(0.002 \mathrm{~mm})$.

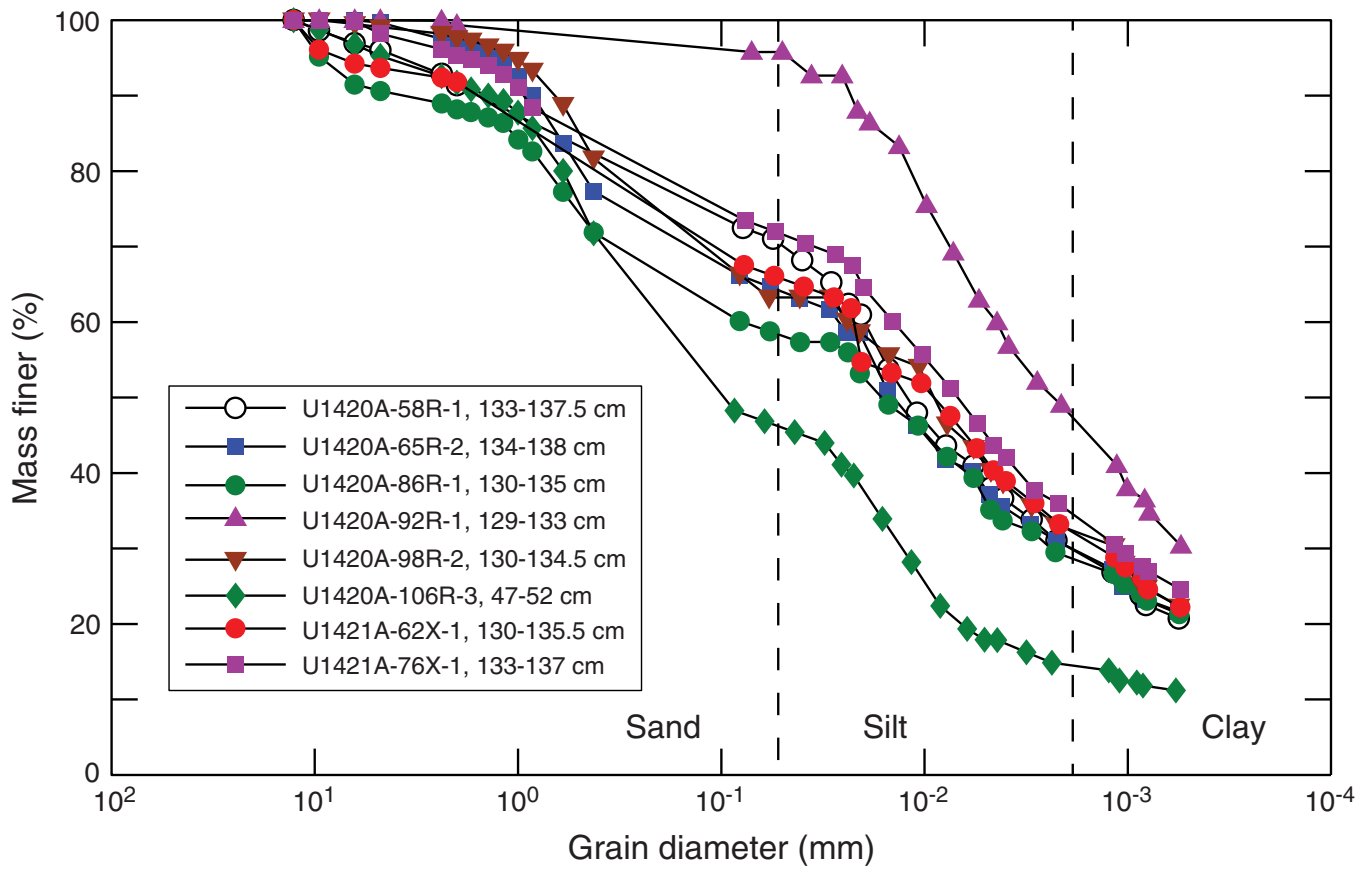

Figure F10. Plots of clay-sized fraction versus (A) $k_{0}$ and (B) $C_{c}$.
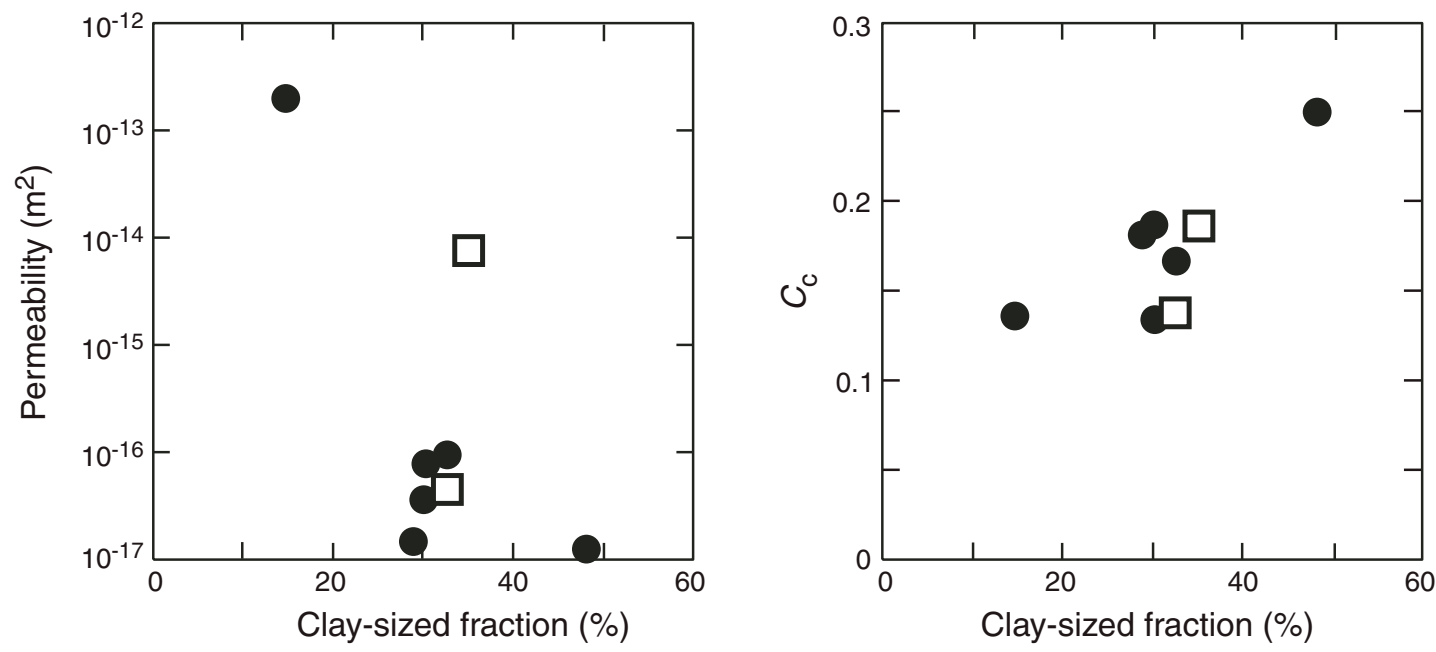

Site U1420

Site U1421 
Table T1. Nomenclature.

\begin{tabular}{|c|c|c|c|}
\hline Variable & Definition & Dimension & Unit \\
\hline$C_{c}$ & Compression index & Dimensionless & - \\
\hline$C_{s}$ & Swelling index & Dimensionless & - \\
\hline$c_{\mathrm{v}}$ & Coefficient of consolidation & $\mathrm{L}^{2} / \mathrm{T}$ & $\mathrm{m}^{2} / \mathrm{s}$ \\
\hline$D$ & Particle diameter & L & $\mathrm{m}$ \\
\hline$D_{50}$ & Median particle diameter & $\mathrm{L}$ & $\mathrm{mm}$ \\
\hline$e^{e}$ & Void ratio & Dimensionless & - \\
\hline$e_{0}$ & Reference void ratio & Dimensionless & - \\
\hline$e_{\sigma a^{\prime}}$ & Void ratio at axial effective stress & Dimensionless & - \\
\hline g & Acceleration due to gravity & $\mathrm{L} / \mathrm{T}^{2}$ & $\mathrm{~m} / \mathrm{s}^{2}$ \\
\hline$H$ & Instantaneous sample height & $\mathrm{L}$ & $\mathrm{m}$ \\
\hline$H_{0}$ & Initial sample height & $\mathrm{L}$ & $\mathrm{m}$ \\
\hline$k$ & Permeability & $\mathrm{L}^{2}$ & $\mathrm{~m}^{2}$ \\
\hline$k_{0}$ & Permeability at reference void ratio & $\mathrm{L}^{2}$ & $\mathrm{~m}^{2}$ \\
\hline$L$ & Effective depth from solution surface to center of hydrometer bulb & $\mathrm{L}$ & $\mathrm{m}$ \\
\hline$m_{\mathrm{p}}$ & Mass fraction of particles remaining in suspension & Dimensionless & - \\
\hline$m_{\mathrm{v}}$ & Coefficient of volume compressibility & $\mathrm{LT}^{2} / \mathrm{M}$ & $1 / \mathrm{Pa}$ \\
\hline$P_{c}$ & Consolidation cell pressure & $\mathrm{M} / \mathrm{LT}^{2}$ & $\mathrm{~Pa}$ \\
\hline$P_{\mathrm{p}}$ & Pore pressure & $\mathrm{M} / \mathrm{LT}^{2}$ & $\mathrm{~Pa}$ \\
\hline$t$ & Time & $\mathrm{T}$ & s \\
\hline$V$ & Volume of solution & $L^{3}$ & $\mathrm{~m}^{3}$ \\
\hline$\Delta u$ & Base excess pressure & $\mathrm{M} / \mathrm{LT}^{2}$ & $\mathrm{~Pa}$ \\
\hline$\varepsilon$ & Axial strain & Dimensionless & - \\
\hline$\varepsilon_{\sigma a^{\prime}}$ & Axial strain at axial effective stress & Dimensionless & - \\
\hline$\dot{\varepsilon}$ & Strain rate & $1 / \mathrm{T}$ & $1 / s$ \\
\hline$\mu$ & Viscosity & $\mathrm{M} / \mathrm{LT}$ & $\mathrm{Pa} \cdot \mathrm{s}$ \\
\hline$\rho$ & Hydrometer reading & $M / L^{3}$ & $\mathrm{~kg} / \mathrm{m}^{3}$ \\
\hline$\rho_{\mathrm{f}}$ & Density of solution without sediment & $\mathrm{M} / \mathrm{L}^{3}$ & $\mathrm{~kg} / \mathrm{m}^{3}$ \\
\hline$\rho_{\mathrm{s}}$ & Specimen grain density & $\mathrm{M} / \mathrm{L}^{3}$ & $\mathrm{~kg} / \mathrm{m}^{3}$ \\
\hline$\sigma$ & Standard deviation of grain size distribution & Dimensionless & - \\
\hline$\sigma_{\mathrm{a}}$ & Total axial stress & $\mathrm{M} / \mathrm{LT}^{2}$ & $\mathrm{~Pa}$ \\
\hline$\sigma_{a}^{\prime}$ & Axial effective stress & $\mathrm{M} / \mathrm{LT}^{2}$ & $\mathrm{~Pa}$ \\
\hline$\phi_{0}$ & Reference porosity & Dimensionless & - \\
\hline
\end{tabular}

Table T2. Data from consolidation and grain size measurements.

\begin{tabular}{|c|c|c|c|c|c|c|c|c|c|c|c|c|c|}
\hline $\begin{array}{l}\text { Core, section, interval } \\
(\mathrm{cm})\end{array}$ & $\begin{array}{c}\text { Depth } \\
\text { CSF-A (m) }\end{array}$ & $\begin{array}{l}\text { Lithologic } \\
\text { unit }\end{array}$ & $\begin{array}{l}\text { CRS } \\
\text { test }\end{array}$ & $e_{0}$ & $\phi_{0}$ & $C_{c}$ & $C_{s}$ & $\begin{array}{c}k_{0} \\
\left(\mathrm{~m}^{2}\right)\end{array}$ & $\begin{array}{c}D_{50} \\
(\mathrm{~mm})\end{array}$ & $\begin{array}{l}\text { Sand } \\
(\%)\end{array}$ & $\begin{array}{l}\text { Silt } \\
(\%)\end{array}$ & $\begin{array}{l}\text { Clay } \\
(\%)\end{array}$ & $\begin{array}{c}\sigma \\
(\varphi)\end{array}$ \\
\hline \multicolumn{14}{|l|}{ 341-U1420A- } \\
\hline 58R-1, 133-137.5 & 546.86 & III & CRSO04 & 0.56 & 0.36 & 0.19 & 0.029 & $3.6 \mathrm{E}-17$ & 0.0122 & 28.5 & 41.2 & 30.3 & 3.7 \\
\hline $65 R-2,134-138$ & 616.23 & III & CRSO03 & 0.58 & 0.37 & 0.13 & 0.023 & $7.8 \mathrm{E}-17$ & 0.0143 & 35.0 & 34.7 & 30.3 & 3.5 \\
\hline 86R-1, 130-135 & 818.43 & III & CRS006 & 0.58 & 0.37 & 0.18 & 0.036 & $1.5 \mathrm{E}-17$ & 0.0162 & 40.9 & 30.1 & 28.9 & 4.1 \\
\hline 92R-1, 129-133 & 876.61 & III & CRS007 & 0.69 & 0.41 & 0.25 & 0.036 & $1.2 \mathrm{E}-17$ & 0.00232 & 4.23 & 47.6 & 48.2 & 2.3 \\
\hline $98 R-2,130-134.5$ & 936.32 & III & CRS008 & 0.51 & 0.34 & 0.17 & 0.024 & $9.4 \mathrm{E}-17$ & 0.00898 & 36.1 & 31.3 & 32.7 & 3.5 \\
\hline $106 \mathrm{R}-3,47-52$ & 1014.20 & III & CRS010 & 0.50 & 0.33 & 0.14 & 0.027 & $2.0 \mathrm{E}-13$ & 0.0969 & 53.1 & 32.4 & 14.6 & 3.2 \\
\hline \multicolumn{14}{|l|}{ 341-U1421A- } \\
\hline $62 X-1,130-135.5$ & 492.63 & II & CRS005 & 0.70 & 0.41 & 0.14 & 0.026 & $4.5 \mathrm{E}-17$ & 0.00899 & 33.4 & 34.0 & 32.7 & 4.0 \\
\hline $76 X-1,133-137$ & 607.05 & II & CRSO09 & 0.69 & 0.41 & 0.19 & 0.035 & $7.6 \mathrm{E}-15$ & 0.00687 & 27.4 & 37.4 & 35.1 & 3.6 \\
\hline
\end{tabular}

CRS = constant-rate-of-strain. All nomenclature is defined in Table T1. 